\title{
Stem/progenitor cells in pituitary organ homeostasis and tumourigenesis
}

\author{
Scott Haston, Saba Manshaei and Juan Pedro Martinez-Barbera \\ Developmental Biology and Cancer Research Programme, Birth Defects Research Centre, UCL Great Ormond Street Institute of Child Health, London, UK \\ Correspondence should be addressed to S Haston or J P Martinez-Barbera: scott.haston.13@ucl.ac.uk or j.martinez-barbera@ucl.ac.uk
}

\section{Abstract}

Evidence for the presence of pituitary gland stem cells has been provided over the last decade using a combination of approaches including in vitro clonogenicity assays, flow cytometric side population analysis, immunohistochemical analysis and genetic approaches. These cells have been demonstrated to be able to self-renew and undergo multipotent differentiation to give rise to all hormonal lineages of the anterior pituitary. Furthermore, evidence exists for their contribution to regeneration of the organ and plastic responses to changing physiological demand. Recently, stem-like cells have been isolated from pituitary neoplasms raising the possibility that a cytological hierarchy exists, in keeping with the cancer stem cell paradigm. In this manuscript, we review the evidence for the existence of pituitary stem cells, their role in maintaining organ homeostasis and the regulation of their differentiation. Furthermore, we explore the emerging concept of stem cells in pituitary tumours and their potential roles in these diseases.

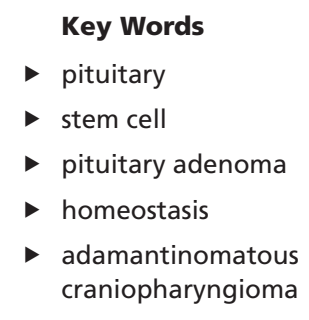

Journal of Endocrinology (2018) 236, R1-R13

\section{Introduction}

The pituitary gland is known as the master regulator of the endocrine system, a title that is justified by the numerous critical physiological functions that it regulates including growth, metabolism, stress responses and reproduction. The organ is composed of anterior (AL), intermediate (IL) and posterior lobes (PL), with the former two being derived from Rathke's pouch, an invagination of the oral ectoderm and the latter being a derivative of the overlying diencephalic neural ectoderm. The AL contains five distinct hormone-producing cell types: somatotrophs, thyrotrophs, lactotrophs, corticotrophs and gonadotrophs, which secrete growth hormone (GH), thyroid-stimulating hormone (TSH), prolactin (PRL), adrenocorticotropin (ACTH) and gonadotropins (FSH and LH), respectively (Kelberman et al. 2009). These secretory cells have been defined by the expression of specificlineage transcription factors that are important for their induction and maintenance. These lineage commitment markers include Sf1, which directs differentiation of the gonadotroph cell lineage (Schimmer \& White 2010), Tpit, which activates proopiomelanocortin (Pomc1) in corticotrophs (Lamolet et al. 2001), and Pit-1, which results in the production of lactotrophs, thyrotrophs and somatotrophs (Dollé et al. 1990). These hormonal lineages are generated during embryonic development and are all specified by birth (Japón et al. 1994) (Fig. 1). Interestingly, Pit-1-independent differentiation of a transient population of thyrotrophs has been observed in the rostral tip of Rathke's pouch, which becomes the pars tuberalis of the pituitary. These cells arise around embryonic day 12, preceding the formation of the mature Pit-1-dependant thyrotrophs that persist into adult life and are lost by the time of birth (Lin et al. 1994).

The pituitary possesses a remarkable capacity for plasticity in regulating the number and proportion of secretory cell types in response to physiological changes, such as puberty and pregnancy (Melmed 2003, Perez-Castro et al. 2012). Recently, it has been demonstrated that the 


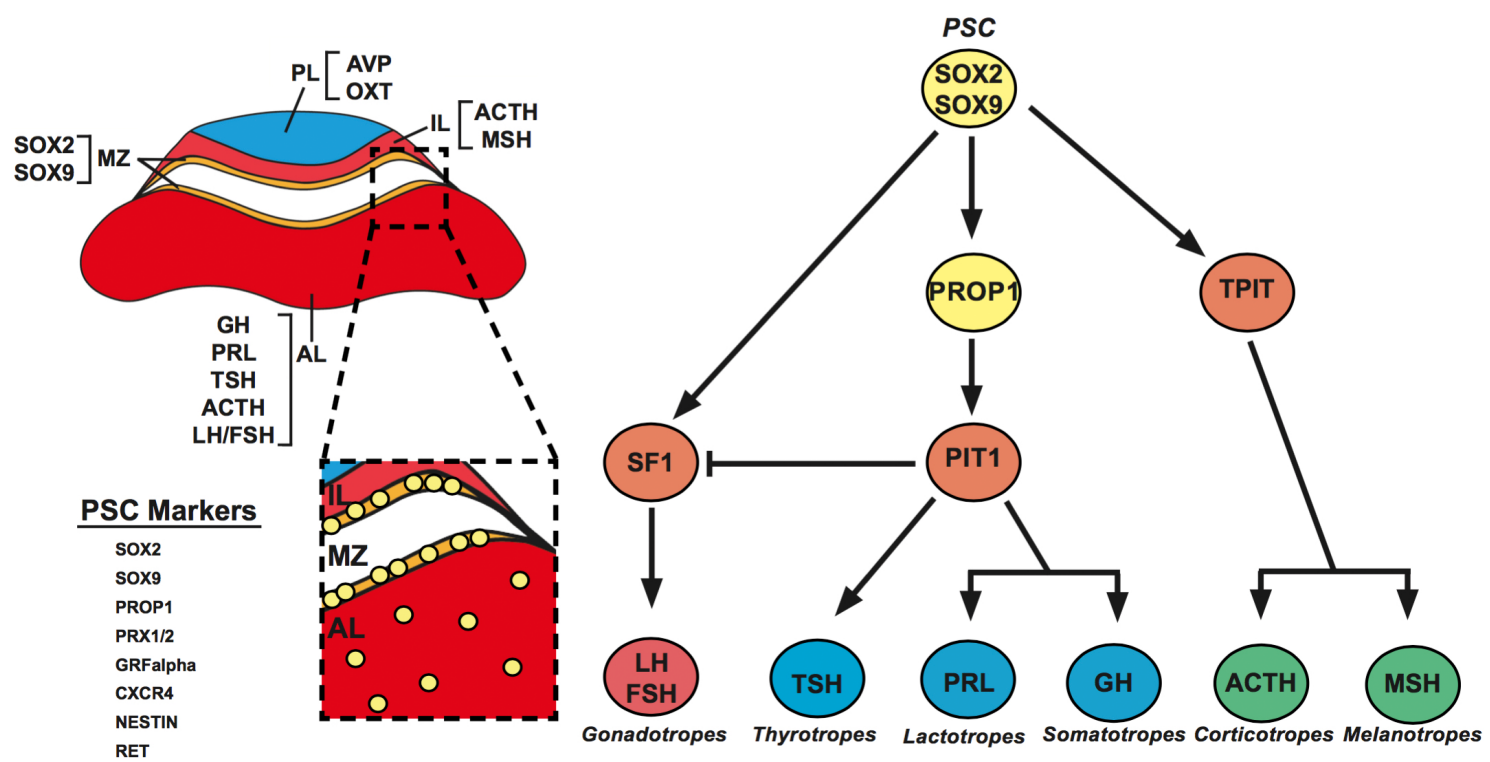

\section{Figure 1}

Left: Schematic representation of a coronal section through an adult mouse pituitary. Anatomical locations of the hormone-expressing cells are indicated in the posterior (PL), intermediate (IL) and anterior (AL) lobes. The PL contains the axons of the hypothalamic magnocellular neurosecretory neurons that release vasopressin (AVP) and oxytocin (OXT). The IL contains melanotrophs and corticotrohs. The AL holds the somatotrophs, lactotrophs, thyrotrophs, corticotrophs and gonadotrophs. PSCs are concentrated in the MZ, at the dorsal region of the AL lining the cleft, and scattered throughout the AL. These cells can be identified through the expression of several PSC markers. Right: A genetic pathway showing the cellular hierarchy of differentiation in the pituitary with essential transcription factors, which regulate lineage commitment.

AL contains populations of stem/progenitor cells, which contribute to the production of hormone-producing cells during development and postnatal life (Garcia-Lavandeira et al. 2015). Stem-like cells have also been identified from pituitary adenomas and other pituitary neoplasias raising the possibility that they represent a tumour-initiating cell population. The elucidation of the mechanisms underlying pituitary stem cell (PSC) self-renewal, differentiation and programmed death may lead to a greater understanding of pituitary homeostasis, physiological plasticity and tumorigenesis. Ultimately, this may inform future translational research on hypopituitarism and neoplasia. This review aims to explore our current understanding of the identity of PSCs, particularly in the adult context, as well as their role in maintaining organ homeostasis and contribution to tumorigenesis.

\section{Pituitary stem cells during embryonic and postnatal life}

\section{Identification of adult pituitary stem cells}

Resident tissue-specific stem cells are found in most organs, where they are critical for normal homeostasis. Stem cells reside in specialised microenvironments known as the niche, which provides molecular cues to maintain stemness and direct their differentiation into transitamplifying and/or terminally differentiated somatic cells. Stem cells are also characterised by their ability to selfrenew, maintaining a long-term pool of undifferentiated progenitors for future rounds of differentiation (Hsu et al. 2014). Therefore, stem cells are able to provide the means for a tissue to maintain homeostatic balance and regeneration following injury (van Es et al. 2012, Patel et al. 2013).

Convincing evidence of the existence of adult PSCs has been gathered over the last decade. These PSCs are thought to reside in the $\mathrm{IL}$, dorsal $\mathrm{AL}$, a region known as the marginal zone (MZ) and dispersed throughout the AL parenchyme. Work by Lepore in 2005 demonstrated that the culture of dissociated pituitary tissue in stem cellpromoting media resulted in the generation of adherent colonies, which express $S 100 \beta$ and have the capacity to differentiate into hormone-producing cells (Lepore et al. 2005). Similar experiments later showed that if dissociated pituitaries are grown in non-adherent conditions, 'pituispheres' can be generated, which efflux verapamilsensitive Hoechst dye, allowing for their identification by flow cytometry (Chen et al. 2005). Further work uncovered that this side population expresses the markers SOX2, SOX9, CD4, CD133 and stem cell antigen-1 (SCA1) (Chen et al. 2009). 
Others employing the use of in vitro clonogenicity assays have uncovered pituitary cells that express PROP1, PRX1/2, GFR 2 2, CXCR4 and NESTIN and possess clonogenic potential (Gleiberman et al. 2008, Garcia-Lavandeira et al. 2009, Nomura et al. 2009, Horiguchi et al. 2012, Rizzoti et al. 2013, Higuchi et al. 2014). NESTIN was also demonstrated to be co-expressed with SOX2 in cells of the MZ; however, its expression is known to be heterogeneous as NESTIN is also expressed in non-hormonal pituitary cells, making it unsuitable as a definitive marker of PSC (Krylyshkina et al. 2005, Vankelecom 2007). PROP1, a transcription factor that is indispensable for pituitary development, has also been found to be expressed in putative PSC populations and has been associated with stemness as its downregulation, along with SOX2, is required for hormonal cell differentiation (Fauquier et al. 2008, Chen et al. 2009, Garcia-Lavandeira et al. 2009, Yoshida et al. 2009, Gremeaux et al. 2012). Moreover, PROP1 has been shown to be required to maintain normal numbers of undifferentiated PSCs (Pérez Millán et al. 2016). Further work analysing PSC side populations has revealed that they express the paired homeodomain protein PRX1 and PRX2, which have been suggested to have functions in the proliferation and maintenance of embryonic pituitary progenitors in Rathke's pouch (Vankelecom 2010, Susa et al. 2012). Expression of the chemokine receptor CXCR4 and its ligand, CXCL12, have also been identified in PSC side populations, along with other cells of the $\mathrm{AL}$, with suggestions that this signalling axis may contribute to maintenance and migration of PSCs (Barbieri et al. 2007, Vankelecom 2010, Horiguchi et al. 2012). Work by GarciaLavandeira has shown that a population of cells located in the MZ coexpress GFR $\alpha 2$, RET and PROP1 (referred to as 'GPS' cells), and it is suggested that these cells contribute to the stem cell niche in the MZ and may function in the regulation of structural guidance and survival of PSCs. Furthermore, this population was observed in both mouse and human pituitaries and found to coexpress the stemness markers SOX2 and SOX9 (Garcia-Lavandeira et al. 2009).

SOX2+ cells, which are negative for expression of hormonal markers, have been found predominantly localised to the MZ with scattered cells throughout the AL. SOX2 has been shown to be expressed in the clonogenic cells in both adherent and non-adherent cultures and isolation of SOX2+ cells by flow cytometry greatly enriched for colony-forming cells. Interestingly, only $1.5-5 \%$ of plated SOX2+ cells were capable of colony formation, indicating that the population is most likely heterogeneous, with only a subpopulation of cells possessing self-renewing capacity (Fauquier et al. 2008, Andoniadou et al. 2012). In the AL,
SOX2 is predominantly co-expressed with SOX9, with partial overlap of $\$ 100 \beta$ expression (Andoniadou et al. 2013, Rizzoti et al. 2013). Genetic lineage tracing experiments following the fate of SOX2+ cells in the pituitary in vivo showed that over long-term tracing (9 months) SOX2+ cells differentiated into all hormone-producing lineages. In addition, a proportion of traced cells express SOX2 and SOX9, but not any commitment or differentiation markers, suggesting self-renewal of the initially labelled SOX2+ cells (Andoniadou et al. 2013).

There is also evidence that supports the existence of a PSC population in humans. Pituispheres have been generated from five human pituitaries following autopsy and were shown to express the PSC markers NESTIN, LHX3 and PITX2. Furthermore, these spheres were shown to be able to express all pituitary hormones upon induction of differentiation (Weiss et al. 2009). Further work demonstrated the existence of a 'GPS' cell population in the human MZ, which colocalised with the stemness markers OCT4, KLF4, SOX2 and SOX9, a situation analogous to that in mouse (Garcia-Lavandeira et al. 2012).

In the past 10 years, there have been great strides in characterising putative PSC populations in both mice and humans. The use of flow cytometry to isolate side populations has provided a plethora of makers of PSC. Clonogenic assays have demonstrated the capability of these cells to both self-renew and differentiate in a multipotent fashion in vitro. Genetic lineage tracing strategies have also provided insights into the existence of adult PSC in vivo, albeit based on the expression of only SOX2 and SOX9. Together these studies identify that populations of cells possessing stem cell characteristics appear to be predominantly, but not exclusively, localised to the MZ. The question remains, however, whether PSC are a single population with multipotent differentiation capacity or distinct populations with more restricted lineage commitments. Further research will be required to solve this question and determine the definitive markers of PSC identity.

Regulation of pituitary stem cell differentiation: insights from embryonic development and organoids

The lack of definitive markers of PSCs has hampered the elucidation of the mechanisms underlying their differentiation in vivo, therefore, limiting our understanding to the analysis of cell populations in vitro. As discussed previously, putative PSC populations can be grown in vitro, as either adherent colonies or as freefloating spheres. These cells can then be differentiated

This work is licensed under a Creative Commons Attribution 3.0 Unported License. 
into all hormone-producing cell types. This has been achieved by different means including culture in the presence of a mixture of growth factors, hormones or conditioned media from differentiated pituitary cell lines (Fauquier et al. 2008, Chen et al. 2009, GarciaLavandeira et al. 2009). Due to the heterogeneous nature of the additives used, it is not possible to determine the exact factors required or the order in which cells must be exposed to them to induce directed differentiation along specific hormonal lineages.

An approach that has been adopted to determine the mechanisms of differentiation is to study the embryonic development of the pituitary, with the assumption that similar mechanisms govern embryonic and adult PSC differentiation. Independent work from several groups have shown the importance of a multitude of signalling molecules and transcription factors in controlling Rathke's pouch progenitor specification, proliferation and differentiation of all hormone-producing cells (Reviwed in Kelberman et al. 2009, Perez-Castro et al. 2012). Work from Sasai's group in 2011 demonstrated the validity of such approach. They utilised mouse embryonic stem cell (ESC) aggregates to study pituitary organogenesis. They uncovered that they could induce Rathke's pouch progenitors (PITX1A+/LHX3+) by combining ESC aggregates with either oral ectoderm (PITX1A+) or hypothalamic identity $(\mathrm{RX}+)$ in the presence of a Shh pathway agonist (Suga et al. 2011). Shh has also been shown to be required for Lhx3 expression in explant cultures of human pituitaries (Treier et al. 2001). Following this, they tested strategies to induce commitment to specific hormonal lineages. Somatotrophs were obtained after a long culture period in the presence of a $\beta$-catenin agonist, cortisol and insulin, albeit at a low efficiency, with less than $6 \%$ of progenitor cells becoming $\mathrm{GH}+$. Corticotroph differentiation was induced more robustly ( $40 \%$ of progenitors became ACTH+) through the action of hypoxia and a Notch pathway inhibitor. These results have also been recapitulated using human ESC and induced pluripotent stem cells (iPSC) demonstrating conserved mechanisms of specification between species (Dincer et al. 2013).

\section{The role of adult pituitary stem cells during organ homeostasis}

The regenerative capacity of the pituitary gland has been tested using transgenic mouse models, in which specific hormonal lineages in adult mice could be genetically ablated. This research has provided evidence for a role of stem/progenitor cells in repopulating the gland. Work by Vankelecom's group, in which somatotrophs $(\mathrm{GH}+)$ were rendered susceptible to diphtheria toxinmediated ablation, revealed that the elimination of this lineage led to expansion of the SOX2+ stem/progenitor compartment, with increased numbers of double SOX2+/GH+ cells (Fu et al. 2012). Further to this, they also demonstrated that the regenerative potential of the organ was age dependant, with older mice failing to recover their $\mathrm{GH}+$ population following ablation (Willems et al. 2016). Interestingly, this reduced regenerative potential correlates with a reduction in PSC during ageing. The Vankelecom group also demonstrated similar regeneration and expansion of the stem/progenitor compartment when lactotrophs (PRL+) were specifically ablated (Fu \& Vankelecom 2012). Both studies, however, failed to show quantitatively consistent re-population of the organ and did not utilise genetic tracing to demonstrate that it was PSC that differentiated during regeneration. In contrast to these results, experimental reduction of the number of corticotrophs (ACTH+), by Drouin's group, found that the contribution of PSC was negligible and that regeneration was attributed to replication of existing corticotrophs (Langlais et al. 2013). Like the previous two studies, the work by Drouin's group did not perform lineage tracing.

As previously mentioned lineage tracing of putative PSCs has been performed by both our own (SOX2+ cell lineage tracing) and Lovell-Badge's group (SOX2+ or SOX9+ cell lineage tracing) (Andoniadou et al. 2013, Rizzoti et al. 2013). Together these results showed that SOX2+ PSC populations differentiate to give rise to all hormonal lineage and self-renew long term. Work by Lovell-Badge's group also performed functional experiments, in which traced SOX2+ or SOX9+ cells could be induced to proliferate in vivo due to the effect of oestradiol and could differentiate to a corticotroph fate following acute adrenalectomy. Interestingly, the authors found that traced cells had a predisposition to becoming $\mathrm{LH}+$ gonadotrophs and lactotrophs (PRL+), with a small number differentiating into somatotrophs $(\mathrm{GH}+)$ (Rizzoti et al. 2013). Together, this work demonstrates that adult PSCs in normal conditions both self-renew and differentiate to form all AL hormonal lineages; however, the number of differentiated cells produced is small indicating low levels of physiological turnover. Furthermore, indirect evidence suggests that PSCs can be recruited under injury conditions to facilitate regeneration of the organ. However, this contribution seems to be limited, therefore indicating that proliferation of differentiated cells is the most likely source of this plasticity in some contexts.

This work is licensed under a Creative Commons Attribution 3.0 Unported License. ded from Bioscientifica.com at $04 / 26 / 2023$ 01:51:13PM via free access 
It is well established that the adult pituitary is an organ with a low cell turnover, estimated to be around $1.5 \%$ of cells per day in adulthood, which declines during the ageing process (Nolan et al. 1998, Levy 2002). Although in certain contexts such as during development, early postnatal life, puberty, pregnancy and lactation proliferation in the pituitary has been observed to increase (Melmed 2003). It has generally been assumed that these proliferating cells represent the terminally differentiated secretory cell populations. Indeed, all differentiated hormonal cells have been shown to possess the capacity to divide, with females showing a proliferation bias towards lactotrophs and males towards somatotrophs (Oishi et al. 1993). Evidence for the involvement of PSCs, as opposed to replication of existing hormonal cells, in pituitary plasticity during pregnancy and lactation is currently sparse. Work by Zhu et al. demonstrated the importance of the Notch signalling pathway in maintaining postnatal SOX2+ PSC self-renewal using a genetically modified mouse line, in which PSCs were depleted through loss of Notch signalling in PROP1-expressing cells. They showed that the numbers of proliferating SOX2+ cells did not increase during gestation and lactation, however, increased proliferation was observed in PIT1+ cells. Furthermore, they revealed similar proliferation dynamics in both PSC-deficient and wild-type contexts. From this they concluded that the SOX2+ PSC were dispensable for the plastic adaptation during pregnancy and lactation. However, by performing bilateral adrenalectomy, the same group showed that PSCs as well as PIT1+ and ACTH+ cells increased proliferation. Interestingly, in the PSC-depleted genetic context, similar increases in proliferation and numbers of ACTH+ cells were observed indicating that the PSC populations' contribution to plasticity was limited. These authors also noted, however, that the SOX2+ PSCs are important for postnatal expansion of the gland, as the proliferative index of the organ was halved in their Notch ablated, PSC-deficient context (Zhu et al. 2015). A recent study, however, reported the expansion of PSC during gestation and at the onset of lactation, but without experimental lineage tracing of PSCs, it is difficult to fully assess their involvement in meeting changing hormonal demands (Vaca et al. 2016). Analysis of PSC markers in rat pituitaries during normal conditions revealed that the number of these cells is at its highest at birth and that a continuous decline occurs throughout adult life. Concomitant with this, proliferation in the gland also decreases with age (Garcia-Lavandeira et al. 2009, Yoshida et al. 2011). In mice, the numbers of SOX2+ cells also decline following birth (Gremeaux et al. 2012).
To gain a more complete understanding of pituitary homeostasis, it is necessary to assess the role of programmed cell death. Apoptosis in the adult pituitary has been shown to occur at a very low rate, with increases observed during pregnancy and the postpartum period (Kulig et al. 1999). Recently, a mechanism has been proposed in which the RET/Pit-1/Arf/p53 signalling axis contributes to the regulation of pituitary cell turnover by apoptosis. The RET receptor and its co-receptor GFRA2 have been shown to be expressed in PSC. Furthermore, RET is also expressed alongside another co-receptor GFRA1 in somatotrophs (Urbano et al. 2000, Japón et al. 2002). These signalling complexes are activated by GDNF, which is expressed in the AL of rat and human pituitaries. RET has been demonstrated to act as a 'dependence receptor' in somatotrophs, where signalling activity is crucial for the survival of these cells (Cañibano et al. 2007). Absence of signalling ligand results in RET complexing with caspase-3 and PLC-delta (PKCd). Following this, caspase-3 becomes activated, processing RET and PKCd, resulting in the phosphorylation of the transcription factors CREB and cEBPa, among others, which leads to excessive Pit-1 transcription (Cañibano et al. 2007, Diaz-Rodriguez et al. 2014). Pit-1 then induces transcription of p19-ARF, subsequent stabilisation and accumulation of p53 and apoptosis. Intriguingly the dependence of Pit-1 in this apoptotic signalling network creates an association with the differentiation of PSC. Further in vivo evidence for the RET/Pit-1/Arf/p53 pathway can be observed in RETknockout mice, which results in expanded somatotroph numbers causing pituitary hyperplasia (Cañibano et al. 2007). Moreover, it has been observed in normal pituitaries that most of the non-apoptotic (TUNEL-negative) and p19-ARF-negative somatotrophs show phosphorylation of the RET receptor, which is indicative of GDNF signalling activity. There is also some evidence that this apoptotic pathway is at play in other hormonal lineages. Following the cessation of lactation, there is an increased number of RET/activated Caspase-3 double positive cells, although the study did not determine whether these cells were lactotrophs (Guillou et al. 2011). There is also evidence for redundancy in AL programmed cell death mechanisms as autocrine production of dopamine has been found to be pro-apoptotic in lactotrophs following lactation (Jaubert et al. 2007). Together, these studies provide evidence for the existence of mechanisms of programmed cell death in terminally differentiated secretory cells of the pituitary, which are necessary for regulating cell number in response to physiological demand. 
The role of stem cells during pituitary tumorigenesis

\section{Cancer stem cells and tumour heterogeneity}

Research over the past few decades has established that, generally, a tumour mass is not a homogenous environment, but rather it consists of a range of cell subpopulations varying in genetic, epigenetic and phenotypic properties (Marusyk \& Polyak 2010, Burrell et al. 2013). This phenomenon, termed intra-tumour heterogeneity, can be explained through the cancer stem cell (CSC) model, whereby tumorigenesis follows a similar mode of development as organogenesis, in a hierarchical manner (Visvader \& Lindeman 2008, Shackleton et al. 2009, Kreso \& Dick 2014). This model proposes that a small population of cancerous cells with stem-like properties, termed CSCs, differentiate and through clonal evolution and environmental differences, make up a heterogeneous tumour bulk (Visvader \& Lindeman 2008, Shackleton et al. 2009).

CSCs, similar to normal stem cells, are thought to have the ability to be maintained by a specific niche, self-renew and differentiate into all cell types within the tumour (Visvader \& Lindeman 2008, Shackleton et al. 2009, Nguyen et al. 2012). In this model, these cells initiate and maintain tumorigenesis, yet, may be more resistant to chemotherapy and radiotherapy than other tumour cells (Abdullah \& Chow 2013, Agliano et al. 2017). This resistance is due to their often (but not always) quiescent or slow cycling states (Stange \& Clevers 2013, MartinezBarbera \& Andoniadou 2016) or the expression of $\mathrm{ABC}$ transporters and high levels of aldehyde dehydrogenases (Abdullah \& Chow 2013).

CSCs were first identified in leukaemia, where it was observed that only a small population of the cancerous cells were capable of colony formation in vitro and cancer propagation in vivo (Bruce \& Van Der Gaag 1963, Park et al. 1971, Sabbath et al. 1985, Griffin et al. 1986). These cells have since been isolated from solid tumours, including breast, brain, colorectal and pancreatic cancers (Southam \& Brunschwig 1961, Hamburger \& Salmon 1977, Al-Hajj et al. 2003, Visvader \& Lindeman 2008). The exact origin of CSCs remains elusive. Some studies suggest that CSCs arise from tissue-specific stem cells following an oncogenic transformation (Bonnet \& Dick 1997, Barker et al. 2009, Zomer etal. 2013), while others have identified that the cells can arise from differentiated cells through reprogramming and dedifferentiation (Griffin et al. 1986, Holczbauer et al. 2013, Friedmann-Morvinski \& Verma 2014).
Irrespective of their origin, CSCs are of high clinical significance, as it is believed that only through eradication of this population will the cancer be treated and relapse prevented.

\section{Cancer stem cells in pituitary adenomas}

Although there has been extensive research in the field of CSCs over the past few decades, evidence for the presence of these cells in pituitary adenomas (PA) has only recently emerged (Carreno et al. 2016). With a prevalence of 78-94 cases/100,000 people (Karavitaki 2012), these tumours of the sellar region are one of the most common intracranial neoplasms (Larkin \& Ansorge 2000). PAs are generally histopathologically benign; yet, they can be locally invasive and clinically relevant, causing endocrine disorders due to the overproduction of hormones. A proportion of them can grow enormously (giant PAs) and develop resistance to treatment (Larkin \& Ansorge 2000, Chanson \& Salenave 2004, Chatzellis et al. 2015, Carreno et al. 2016).

PAs represent a varied group of tumours, can be familial or sporadic, and are classified according to their endocrinological activity (hormone-secreting or nonfunctional), clinical manifestation, driver mutations and histological features (Larkin \& Ansorge 2000, Di Ieva et al. 2014, Syro et al. 2015, Carreno et al. 2016). These tumours are generally recognised as monoclonal tumours, through evidence from X-chromosome inactivation and allelotype analyses (Alexander et al. 1990, Herman et al. 1990, Schulte et al. 1991, Ma et al. 2002). However, some studies have challenged this idea, having identified different clonality pre- and post-recurrence or between primary tumours and their metastases in rare malignant cases (Clayton et al. 2000, Clayton \& Farrell 2001, 2004, Buch et al. 2002).

A number of studies have isolated cells within human and murine PAs (Xu et al. 2009, Hosoyama et al. 2010, Chen et al. 2014, Donangelo et al. 2014, Mertens et al. 2015), fulfilling some or all of the CSC criteria as follows: (1) clonogenic ability in vitro, (2) stem cell marker expression (e.g. CD133, CD166, SOX2, SCA1), (3) multipotency, (4) resistance to chemotherapeutic agents, (5) ability to initiate de novo tumours when transplanted into immunocompromised hosts (Welte et al. 2010, Martinez-Barbera \& Andoniadou 2016). Other properties such as their ability to efflux Hoechst 33342 DNA-binding dye (through ABC transporters (Abdullah \& Chow 2013) have also been used as an identifying marker of these cells (Chen et al. 2014), similar to PSC as previously described. http://joe.endocrinology-journals.org https://doi.org/10.1530/JOE-17-0258
(C) 2018 The authors Published by Bioscientifica Ltd. Printed in Great Britain
This work is licensed under a Creative Commons Attribution 3.0 Unported License. ded from Bioscientifica.com at 04/26/2023 01:51:13PM via free access 
The first identification of CSCs from PA were reported by Xu and coworkers, whereby they isolated a population of cells from hormone-producing and non-producing benign adenomas, fulfilling most of the criteria above (Carreno et al. 2016, Xu et al. 2009). These cells were able to form floating sphere colonies similar to those formed by adult PSC (Chen et al. 2005), when grown in serumfree stem cell-promoting media. They also expressed pituitary specific markers such as PIT1 and markers of 'stemness' such as OCT4, NOTCH4, CD133 and NESTIN. Furthermore, they displayed chemotherapeutic resistance, could differentiate into hormone-producing cells in culture and initiated pituitary tumours when serially transplanted into NOD/SCID mice. Chen and coworkers were able to show similar results through isolation of CD133 and NESTIN-expressing cells from PA, which were able to initiate synaptophysin-positive tumours when xenotransplanted subcutaneously (Chen et al. 2014).

Other studies have also found populations within PAs with CSC properties. Work by Mertens and coworkers reported the identification of a side population within human adenomas that, when purified of endothelial and immune cells, expressed stemness markers such as SOX2, NESTIN and CXCR4 and epithelial-mesenchymal transition-linked factors (Mertens et al. 2015). This cell population had clonogenic, sphere-forming potential in culture, could be serial passaged and differentiated into hormone-producing cells. In contrast to previous studies, these human adenoma cells failed to expand when xenografted into SCID mice; however, they could identify a similar side population in the AtT20 pituitary tumour cell line, which expressed SOX2 and CXCR4, and can form de novo tumours in xenograft transplantations.

Supporting these results, Würth and coworkers recently published a study reporting the isolation of CSC-like cell populations from 38 human PA tumours (Wurth et al. 2016). These cells were CD133+, had clonogenic potential and could form spheres in vitro. They also expressed well-known stem cell markers such as OCT4, SOX2 and NESTIN and had the potential to differentiateinto hormoneproducing cells. Similar to the previously mentioned study, no pituitary tumour formation was observed in immunodeficient mouse xenograft experiments. However, it was shown that the human PA stem cells, when grafted into zebrafish embryos were pro-angiogenic and invasive, demonstrating their CSC-like properties in this alternative in vivo model (Wurth et al. 2016).

More recently, Manoranjan and coworkers compared and characterised PAs with high and low expression of
CD15, a neural stem cell marker for CSCs in other brain tumours (Mao et al. 2009, Read et al. 2009). It was found that PAs that were enriched for CD15, also expressed SOX2 and PAX7 to a significantly higher degree than the CD15 $5^{\text {Low }}$ tumours. When isolated, the CD15+ cell population was able to form spheres in culture and initiate pituitary tumours in mouse xenotransplant experiments (Manoranjan et al. 2016). Interestingly, it was also found that recurrent PAs contain a larger population of the CD15+ cells than other non-recurrent PAs, in agreement with other studies correlating numbers of CSCs within a tumour with its aggressiveness (Singh et al. 2003, Pallini et al. 2011).

The presence of CSCs does not preclude that other stem cells may exist within the tumours. For example, Orciani and coworkers identified and isolated CD133expressing mesenchymal stem cells from growth hormone-expressing and non-secreting PA (Orciani et al. 2014). This subpopulation had osteogenic, chondrogenic and adipogenic differentiation potential and expressed 'stemness' markers such as OCT4 and NANOG. These cells, however, failed to differentiate into hormoneproducing cells, and it was hypothesised that two different populations of stem cells might exist within pituitary tumours (Orciani et al. 2014). A study from Megnis and coworkers isolated a population of cells from hormone-secreting and non-secreting PAs that did not express markers of pituitary progenitor cells or CD133. The authors concluded that these cells were multipotent mesenchymal stromal cells, but not stem cells, due to their limited self-renewal potential (Megnis et al. 2016). Further studies are needed to determine whether these cell populations with CSC-associated characteristics may have a role in maintaining and supporting adenoma formation alongside pituitary cancer stem cells (Orciani et al. 2014, Megnis et al. 2016).

Finally, a recent study on the activation of the MAPK/ERK pathway during pituitary development has provided evidence for a population of proliferative SOX2-expressing cells within human papillary craniopharyngioma (PCP) tumours (Haston et al. 2017). PCPs are rare pituitary tumours, mostly occurring in adults, and generally harbouring BRAF p.V600E mutations (Brastianos et al. 2014). Although benign, they can be clinically aggressive and associated with high morbidity (Brastianos et al. 2014, Haston et al. 2017). It was shown that despite the expression of BRAF V600E protein throughout the tumour, only a small population of cells activated MAPK/ERK pathway. Furthermore, these cells http://joe.endocrinology-journals.org
https://doi.org/10.1530/JOE-17-0258
(C) 2018 The authors Published by Bioscientifica Ltd. Printed in Great Britain
This work is licensed under a Creative Commons Attribution 3.0 Unported License.

ded from Bioscientifica.com at 04/26/2023 01:51:13PM via free access 
did not express pituitary differentiation markers. Further characterisation revealed that these cells express SOX2 and represent the major proliferative cell population within human PCP. The study suggests that activated MAPK/ERK bestows proliferative capacity upon a small subpopulation of SOX2+ cells while impairing their differentiation. Further investigation into the nature of these cells is needed to verify the existence of a CSC population within human PCPs (Haston et al. 2017).

Overall, there has been rising evidence for the existence of a CSC population within PAs and other pituitary tumour types. Some studies have been able to characterise the potential CSCs in transplantation experiments (Xu et al. 2009, Chen et al. 2014, Manoranjan et al. 2016, Wurth et al. 2016), while others have only presented gene expression profiles and assessed their clonogenic and differentiation capacity (Mertens et al. 2015, Haston et al. 2017). There is also evidence for other types of CSCs within PA of a non-pituitary cell lineage origin (Orciani et al. 2014, Megnis et al. 2016). Once the presence of CSCs within pituitary tumours has been fully verified and characterised, effort should be made to target these cells to optimise treatment of pituitary neoplasms.

Stem cells may non-cell-autonomously promote and maintain tumourigenesis in adamantinomatous craniopharyngioma

Adamantinomatous craniopharyngioma (ACP) is another type of benign yet clinically aggressive pituitary tumour of Rathke's pouch origin (Andoniadou et al. 2012). These tumours are mostly paediatric and make up $5-11 \%$ of all of the brain tumours in children (Hölsken et al. 2016). Experiments in ACP mouse models have provided evidence that PSCs can initiate and promote tumourigenesis non-cell-autonomously, rather than cell-autonomously as proposed in the CSC model.

It has been found that the majority of ACP tumours harbour mutations in the CTNNB1 gene, encoding $\beta$-catenin (Buslei et al. 2005). These mutations are thought to impair the proteosomal degradation of this protein, resulting in its nucleo-cytoplasmic accumulation and subsequent upregulation of the Wnt pathway (Buslei et al. 2005, 2007, Andoniadou et al. 2012, Martinez-Barbera 2015). These data were used to make the first genetically engineered mouse model (GEMM) of ACP by targeting Rathke's pouch (RP) progenitors with a degradationresistant form of $\beta$-catenin in Hesx $1^{\mathrm{Cre} /+}$; Ctnnb1 $1^{\text {lox(ex3)/+ }}$ mice (Gaston-Massuet et al. 2011). The successful induction of tumours with similar properties to human ACP established that targeting RP progenitors with oncogenic $\beta$-catenin is sufficient to form tumours; hence, CTNNB1 mutations are drivers of ACP tumourigenesis in mouse and humans (Gaston-Massuet et al. 2011, MartinezBarbera 2015, Martinez-Barbera \& Andoniadou 2016).

The ACP mouse model presented with clusters of cells accumulating nucleo-cytoplasmic $\beta$-catenin, an immunohistochemical hallmark of human ACP (Hofmann et al. 2006, Gaston-Massuet et al. 2011). Cluster cells expressed 'stemness' markers, such as SOX2, CyclinD2, p27 KIP1 and NESTIN, did not proliferate and did not express any commitment or differentiation markers. The tumorigenic pituitaries in the ACP mouse model contained up to three times more cells with clonogenic potential when cultured in stem cellpromoting medium as compared to control pituitaries, signifying an expansion of the stem cell compartment (Gaston-Massuet et al. 2011). Whether CSCs are present in these mutant pituitaries remains as yet to be determined (Gaston-Massuet et al. 2011, Carreno et al. 2016, Martinez-Barbera \& Andoniadou 2016). Interestingly, when mutant $\beta$-catenin was expressed in committed progenitors or differentiated hormoneproducing cells, tumours did not form, suggesting that progenitors/stem cells may play a critical role in tumour induction. This led to the development of a second mouse model specifically targeting SOX2+ cells with oncogenic $\beta$-catenin in Sox $2^{\text {CreERT2/+; }}$ Ctnnb1 ${ }^{\text {Lox }(e x 3) /+}$ mice (Andoniadou et al. 2013). This model also developed synaptophysin-negative tumours and presented with nucleocytoplasmic $\beta$-catenin-accumulating cell clusters.

Interestingly, when genetic lineage traced with a YFP reporter, it was shown that cluster cells originated from the SOX $2+$ cells targeted with mutant $\beta$-catenin (Andoniadou et al. 2013). However, the tumour bulk was found to be YFP negative, suggesting that tumour cells had a different cell of origin to the mutation-sustaining SOX2+ cells. This is in contrast to the CSC model, where the tumour is clonally derived from the initial mutationsustaining cell (Carreno et al. 2016) (Fig. 2).

Molecular studies revealed that cluster cells from the ACP mouse models showed distinctive expression of several chemokines, cytokines and growth factors (Andoniadou et al. 2012, 2013), suggesting a potential paracrine model of tumour induction and maintenance. In this model, the oncogene-sustaining stem cells induce the formation of CSCs, which act as the tumour cell of 
origin giving rise to the bulk of tumour cells (Andoniadou et al. 2013, Martinez-Barbera \& Andoniadou 2016). It was proposed that these paracrine signals could be acting on the cells directly or indirectly by promoting tumorigenesis through changes in the microenvironment (Andoniadou et al. 2013, Martinez-Barbera \& Andoniadou 2016).

Although still an emerging field, non-cell autonomous induction and promotion of tumour formation has previously been described in a number of cases (Nicolas et al. 2003, Park et al. 2011, Laberge et al. 2012, Deschene et al. 2014, Plaks et al. 2015, Di Mitri \& Alimonti 2016, Mescher et al. 2017). There is an opportunity for more research to characterise the exact role of these $\beta$-cateninaccumulating cell clusters and their paracrine secretions in mouse and human ACP.

\section{Concluding remarks}

The pituitary gland, also referred to as the master gland, is the organ responsible for the regulation of critical endocrine functions. There is now evidence for a population of stem cells within this organ, which are mostly active during development and early postnatal life. These PSC may also contribute to the organ's regenerative capacity as well as its plastic nature, participating in the homeostatic balance of hormone-producing cells through different physiological events.
Over the past decade, there has been extensive research characterising this PSC population in mice and humans. Lineage tracing has shown evidence of adult PSCs capable of differentiation into all hormone-producing cell types in vivo and flow cytometric analyses have identified markers for this cell population. Clonogenic assays have verified the isolated cell populations' ability to self-renew and differentiate in vitro. The regenerative capacity of PSC has also been explored through selective ablation of specific pituitary hormonal lineages. However, due to the lack of lineage tracing, it is difficult to definitively assess whether the PSCs are responsible for replenishing the ablated populations. Unresolved questions remain, such as whether there is a single population with multipotent differentiation potential within the pituitary or distinct populations with more restricted commitments. Furthermore, recent advances in characterising the molecular markers of PSC will facilitate the elucidation of the molecular mechanisms underlying their differentiation.

In addition to their role in normal physiology, there is now evidence for the involvement of PSCs during tumorigenesis. Many studies have shown the presence of populations of undifferentiated cells with clonogenic ability within pituitary tumours suggesting that the CSC model may be relevant to pituitary neoplasms. Finally, research on adamantinomatous craniopharyngioma has

\section{Traditional Cancer Stem Cell Model \\ Non-cell Autonomous Cancer Stem Cell}
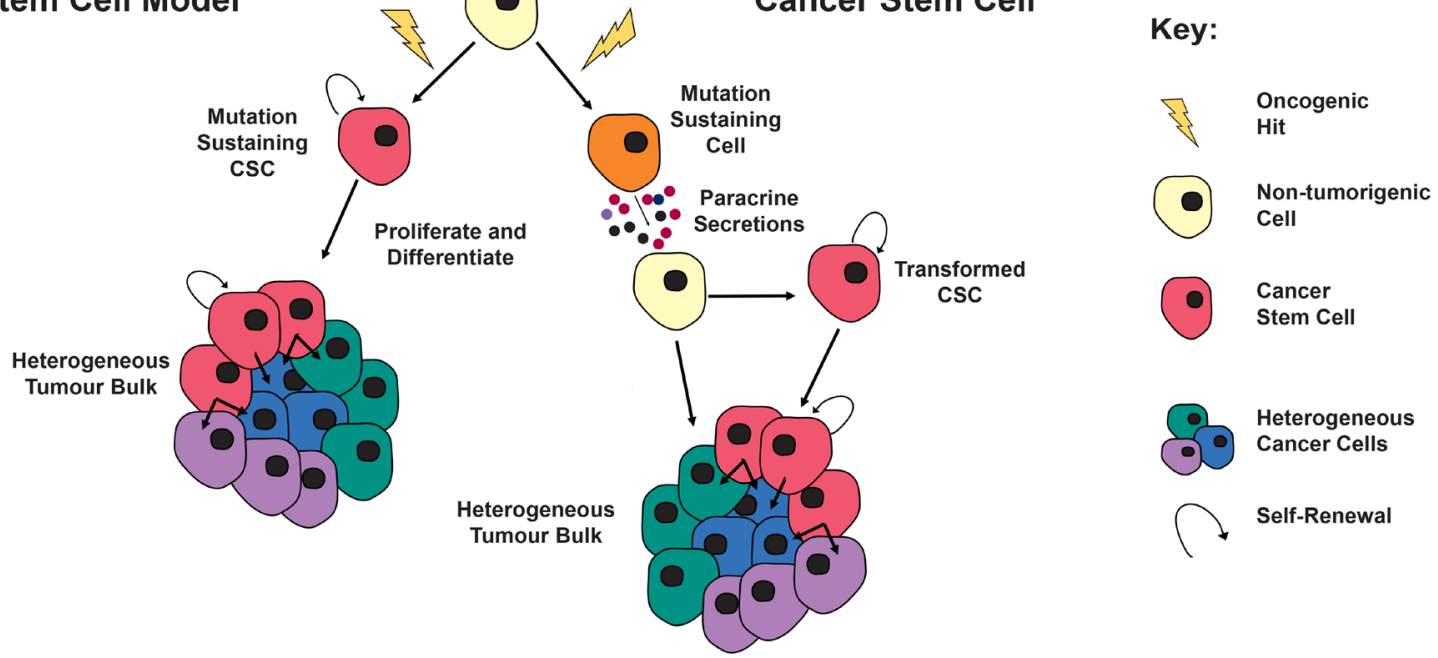

\section{Figure 2}

Left: The CSC model posits that the mutation-sustaining cells, a stem cell, committed progenitor or differentiated cell, generate progeny that constitute the bulk of the tumour cell-autonomously (red cells). These CSCs are able to persist in the tumour to continuously give rise to new tumour cells (green, blue and purple cells), similar to the role of somatic stem cells in normal tissue homeostasis. Right: The non-cell autonomous model of tumorigenesis differs in that the mutation-sustaining cell (orange cell) is not the cell of origin for the tumour. Instead this mutated cell, through paracrine interactions, causes transformation of a neighbouring cell (yellow cell) that can cell-autonomously generate the tumour, either though simple clonal expansion or perhaps through the generation of CSCs (red cells), which give rise to a tumour, as per the canonical cancer stem cell model. 
provided evidence for a non-cell autonomous mechanism of tumour formation, in contrast to the conventional CSC model. A greater understanding of PSC regulation in both physiological and pathological contexts will not only aid in improving our basic understanding, but will ultimately help design novel treatments against hypopituitarism and pituitary tumours.

\section{Declaration of interest}

The authors declare that there is no conflict of interest that could be perceived as prejudicing the impartiality of this review.

\section{Funding}

This work was supported by the Medical Research Council (MRC) (Grant MR/M000125/1, Children with Cancer UK (Grant 164402) and by the National Institute for Health Research Biomedical Research Centre at Great Ormond Street Hospital for Children National Health Service Foundation Trust and University College London. S H holds a Wellcome Trust PhD Fellowship. J P M-B is a Great Ormond Street Children Hospital Charity Principal Investigator

\section{Author contribution statement}

All authors contributed equally to the writing of the manuscript. $\mathrm{S} \mathrm{H}$ and S M generated the figures.

\section{Acknowledgements}

The authors would like to thank Jose Mario Gonzalez-Meljem for assistance in generating the figures as well as Sara Pozzi, Gabriela Carreno and Leonidas Panousopoulos for critical reading of the manuscript.

\section{References}

Abdullah LN \& Chow EK-H 2013 Mechanisms of chemoresistance in cancer stem cells. Clinical and Translational Medicine 2 3. (https://doi. org/10.1186/2001-1326-2-3)

Agliano A, Calvo A \& Box C 2017 The challenge of targeting cancer stem cells to halt metastasis. Seminars in Cancer Biology 44 25-42. (https:// doi.org/10.1016/j.semcancer.2017.03.003)

Al-Hajj M, Wicha MS, Benito-Hernandez A, Morrison SJ \& Clarke MF 2003 Prospective identification of tumorigenic breast cancer cells. PNAS 100 3983-3988. (https://doi.org/10.1073/pnas.0530291100)

Alexander JM, Biller BM, Bikkal H, Zervas NT, Arnold A \& Klibanski A 1990 Clinically nonfunctioning pituitary tumors are monoclonal in origin. Journal of Clinical Investigation 86 336-340. (https://doi. org/10.1172/JCI114705)

Andoniadou CL, Gaston-Massuet C, Reddy R, Schneider RP, Blasco MA, Le Tissier P, Jacques TS, Pevny LH, Dattani MT \& Martinez-Barbera JP 2012 Identification of novel pathways involved in the pathogenesis of human adamantinomatous craniopharyngioma. Acta Neuropathologica 124 259-271. (https://doi.org/10.1007/s00401-012-0957-9)

Andoniadou CL, Matsushima D, Mousavy Gharavy SN, Signore M, Mackintosh AI, Schaeffer M, Gaston-Massuet C, Mollard P, Jacques TS, Le Tissier P, et al. 2013 Sox2+ stem/progenitor cells in the adult mouse pituitary support organ homeostasis and have tumor-inducing potential. Cell Stem Cell 13 433-445. (https://doi. org/10.1016/j.stem.2013.07.004)
Barbieri F, Bajetto A, Porcile C, Pattarozzi A, Schettini G \& Florio T 2007 Role of stromal cell-derived factor 1 (SDF1/CXCL12) in regulating anterior pituitary function. Journal of Molecular Endocrinology 38 383-389. (https://doi.org/10.1677/JME-06-0014)

Barker N, Ridgway RA, van Es JH, van de Wetering M, Begthel H, van den Born M, Danenberg E, Clarke AR, Sansom OJ \& Clevers H 2009 Crypt stem cells as the cells-of-origin of intestinal cancer. Nature $\mathbf{4 5 7}$ 608-611. (https://doi.org/10.1038/nature07602)

Bonnet D \& Dick JE 1997 Human acute myeloid leukemia is organized as a hierarchy that originates from a primitive hematopoietic cell. Nature Medicine 3 730-737. (https://doi.org/10.1038/nm0797-730)

Brastianos PK, Taylor-Weiner A, Manley PE, Jones RT, Dias-Santagata D, Thorner AR, Lawrence MS, Rodriguez FJ, Bernardo LA, Schubert L, et al. 2014 Exome sequencing identifies BRAF mutations in papillary craniopharyngiomas. Nature Genetics 46 161-165. (https://doi.org/10.1038/ng.2868)

Bruce WR \& van der Gaag H 1963 A quantitative assay for the number of murine lymphoma cells capable of proliferation in vivo. Nature 199 79-80. (https://doi.org/10.1038/199079a0)

Buch H, El-Hadd T, Bicknell J, Simpson DJ, Farrell WE \& Clayton RN 2002 Pituitary tumours are multiclonal from the outset: evidence from a case with dural metastases. Clinical Endocrinology 56 817-822. (https://doi.org/10.1046/j.1365-2265.2002.01524.x)

Burrell RA, McGranahan N, Bartek J \& Swanton C 2013 The causes and consequences of genetic heterogeneity in cancer evolution. Nature 501 338-345. (https://doi.org/10.1038/nature12625)

Buslei R, Nolde M, Hofmann B, Meissner S, Eyupoglu IY, Siebzehnrübl F, Hahnen E, Kreutzer J \& Fahlbusch R 2005 Common mutations of $\beta$-catenin in adamantinomatous craniopharyngiomas but not in other tumours originating from the sellar region. Acta Neuropathologica 109 589-597. (https://doi.org/10.1007/s00401-005-1004-x)

Buslei R, Hölsken A, Hofmann B, Kreutzer J, Siebzehnrubl F, Hans V, Oppel F, Buchfelder M, Fahlbusch R \& Blümcke I 2007 Nuclear $\beta$-catenin accumulation associates with epithelial morphogenesis in craniopharyngiomas. Acta Neuropathologica 113 585-590. (https://doi. org/10.1007/s00401-006-0184-3)

Cañibano C, Rodriguez NL, Saez C, Tovar S, Garcia-Lavandeira M, Borrello MG, Vidal A, Costantini F, Japon M, Dieguez C, et al. 2007 The dependence receptor Ret induces apoptosis in somatotrophs through a Pit-1/p53 pathway, preventing tumor growth. EMBO Journal 26 2015-2028. (https://doi.org/10.1038/sj.emboj.7601636)

Carreno G, Gonzalez-Meljem JM, Haston S \& Martinez-Barbera JP 2016 Stem cells and their role in pituitary tumorigenesis. Molecular and Cellular Endocrinology 445 27-34. (https://doi.org/10.1016/j.mce.2016.10.005)

Chanson P \& Salenave S 2004 Diagnosis and treatment of pituitary adenomas. Minerva Endocrinologica 29 241-275.

Chatzellis E, Alexandraki KI, Androulakis II \& Kaltsas G 2015 Aggressive pituitary tumors. Neuroendocrinology 101 87-104. (https://doi. org/10.1159/000371806)

Chen J, Hersmus N, Van Duppen V, Caesens P, Denef C \& Vankelecom H 2005 The adult pituitary contains a cell population displaying stem/ progenitor cell and early embryonic characteristics. Endocrinology 146 3985-3998. (https://doi.org/10.1210/en.2005-0185)

Chen J, Gremeaux L, Fu Q, Liekens D, Van Laere S \& Vankelecom H 2009 Pituitary progenitor cells tracked down by side population dissection. Stem Cells 27 1182-1195. (https://doi.org/10.1002/stem.51)

Chen L, Ye H, Wang X, Tang X, Mao Y, Zhao Y, Wu Z, Mao XO, Xie L, Jin $\mathrm{K}$, et al. 2014 Evidence of brain tumor stem progenitor-like cells with low proliferative capacity in human benign pituitary adenoma. Cancer Letters 349 61-66. (https://doi.org/10.1016/j.canlet.2014.03.031)

Clayton RN \& Farrell WE 2001 Clonality of pituitary tumours: more complicated than initially envisaged? Brain Pathology 11 313-327. (https://doi.org/10.1111/j.1750-3639.2001.tb00402.x)

Clayton RN \& Farrell WE 2004 Pituitary tumour clonality revisited. Frontiers of Hormone Research 32 186-204. (https://doi.org/10.1159/000079045)

Clayton RN, Pfeifer M, Atkinson AB, Belchetz P, Wass JA, Kyrodimou E, Vanderpump M, Simpson D, Bicknell J \& Farrell WE 2000 Different

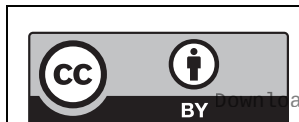

This work is licensed under a Creative Commons Attribution 3.0 Unported License. Aed from Bioscientifica com at $04 / 26 / 2023$ 01:51:13PM 
patterns of allelic loss (loss of heterozygosity) in recurrent human pituitary tumors provide evidence for multiclonal origins. Clinical Cancer Research 6 3973-3982.

Deschene ER, Myung P, Rompolas P, Zito G, Sun TY, Taketo MM, Saotome I \& Greco V 2014 -Catenin activation regulates tissue growth non-cell autonomously in the hair stem cell niche. Science 343 1353-1356. (https://doi.org/10.1126/science.1248373)

Diaz-Rodriguez E, Garcia-Rendueles AR, Ibáñez-Costa A, GutierrezPascual E, Garcia-Lavandeira M, Leal A, Japon MA, Soto A, Venegas E, Tinahones FJ, et al. 2014 Somatotropinomas, but not nonfunctioning pituitary adenomas, maintain a functional apoptotic RET/Pit1/ARF/ p53 pathway that is blocked by excess GDNF. Endocrinology $\mathbf{1 5 5}$ 4329-4340. (https://doi.org/10.1210/en.2014-1034)

Dincer Z, Piao J, Niu L, Ganat Y, Kriks S, Zimmer B, Shi S-H, Tabar V \& Studer L 2013 Specification of functional cranial placode derivatives from human pluripotent stem cells. Cell Reports 5 1387-1402. (https://doi.org/10.1016/j.celrep.2013.10.048)

Dollé P, Castrillo JL, Theill LE, Deerinck T, Ellisman M \& Karin M 1990 Expression of GHF-1 protein in mouse pituitaries correlates both temporally and spatially with the onset of growth hormone gene activity. Cell 60 809-820. (https://doi.org/10.1016/00928674(90)90095-v)

Donangelo I, Ren SG, Eigler T, Svendsen C \& Melmed S 2014 Sca1+ murine pituitary adenoma cells show tumor-growth advantage. EndocrineRelated Cancer 21 203-216. (https://doi.org/10.1530/ERC-13-0229)

van Es JH, Sato T, van de Wetering M, Lyubimova A, Nee ANY, Gregorieff A, Sasaki N, Zeinstra L, van den Born M, Korving J, et al. 2012 Dll1+ secretory progenitor cells revert to stem cells upon crypt damage. Nature Cell Biology 14 1099-1104. (https://doi.org/10.1038/ncb2581)

Fauquier T, Rizzoti K, Dattani M, Lovell-Badge R \& Robinson ICAF 2008 SOX2-expressing progenitor cells generate all of the major cell types in the adult mouse pituitary gland. PNAS 105 2907-2912. (https:// doi.org/10.1073/pnas.0707886105)

Friedmann-Morvinski D \& Verma IM 2014 Dedifferentiation and reprogramming: origins of cancer stem cells. EMBO Reports $\mathbf{1 5}$ 244-253. (https://doi.org/10.1002/embr.201338254)

Fu Q \& Vankelecom H 2012 Regenerative capacity of the adult pituitary: multiple mechanisms of lactotrope restoration after transgenic ablation. Stem Cells and Development 21 3245-3257. (https://doi.org/10.1089/ scd.2012.0290)

Fu Q, Gremeaux L, Luque RM, Liekens D, Chen J, Buch T, Waisman A, Kineman R \& Vankelecom H 2012 The adult pituitary shows stem/ progenitor cell activation in response to injury and is capable of regeneration. Endocrinology 153 3224-3235. (https://doi.org/10.1210/ en.2012-1152)

Garcia-Lavandeira M, Quereda V, Flores I, Saez C, Diaz-Rodriguez E, Japon MA, Ryan AK, Blasco MA, Dieguez C, Malumbres M, et al. 2009 A GRFa2/Prop1/Stem (GPS) cell niche in the pituitary. PLoS ONE 4 e4815. (https://doi.org/10.1371/journal.pone.0004815)

Garcia-Lavandeira M, Saez C, Diaz-Rodriguez E, Perez-Romero S, Senra A, Dieguez C, Japon MA \& Alvarez CV 2012 Craniopharyngiomas express embryonic stem cell markers (SOX2, OCT4, KLF4, and SOX9) as pituitary stem cells but do not coexpress RET/GFRA3 receptors. Journal of Clinical Endocrinology and Metabolism 97 E80-E87. (https:// doi.org/10.1210/jc.2011-2187)

Garcia-Lavandeira M, Diaz-Rodriguez E, Bahar D, Garcia-Rendueles AR, Rodrigues JS, Dieguez C \& Alvarez CV 2015 Pituitary cell turnover: from adult stem cell recruitment through differentiation to death. Neuroendocrinology 101 175-192. (https://doi. org/10.1159/000375502)

Gaston-Massuet C, Andoniadou CL, Signore M, Jayakody SA, Charolidi N, Kyeyune R, Vernay B, Jacques TS, Taketo MM, Le Tissier P, et al. 2011 Increased Wingless (Wnt) signaling in pituitary progenitor/stem cells gives rise to pituitary tumors in mice and humans. PNAS $\mathbf{1 0 8}$ 11482-11487. (https://doi.org/10.1073/pnas.1101553108)

Gleiberman AS, Michurina T, Encinas JM, Roig JL, Krasnov P, Balordi F, Fishell G, Rosenfeld MG \& Enikolopov G 2008 Genetic approaches identify adult pituitary stem cells. PNAS 105 6332-6337. (https://doi. org/10.1073/pnas.0801644105)

Gremeaux L, Fu Q, Chen J \& Vankelecom H 2012 Activated phenotype of the pituitary stem/progenitor cell compartment during the earlypostnatal maturation phase of the gland. Stem Cells and Development 21 801-813. (https://doi.org/10.1089/scd.2011.0496)

Griffin JD, Löwenberg B \& Lowenberg B 1986 Clonogenic cells in acute myeloblastic leukemia. Blood 68 1185-1195.

Guillou A, Romanò N, Bonnefont X, Le Tissier P, Mollard P \& Martin AO 2011 Modulation of the tyrosine kinase receptor Ret/glial cell-derived neurotrophic factor (GDNF) signaling: a new player in reproduction induced anterior pituitary plasticity? Endocrinology 152 515-525. (https://doi.org/10.1210/en.2010-0673)

Hamburger AW \& Salmon SE 1977 Primary bioassay of human tumor stem cells. Science 197 461-463. (https://doi.org/10.1126/ science.560061)

Haston S, Pozzi S, Carreno G, Manshaei S, Panousopoulos L, GonzalezMeljem JM, Apps JR, Virasami A, Thavaraj S, Gutteridge A, et al. 2017 MAPK pathway activation in the embryonic pituitary results in stem cell compartment expansion, differentiation defects and provides insights into the pathogenesis of papillary craniopharyngioma. Development 2 dev.150490. (https://doi.org/10.1242/dev.150490)

Herman V, Fagin J, Gonsky R, Kovacs K \& Melmed S 1990 Clonal origin of pituitary adenomas. Journal of Clinical Endocrinology and Metabolism 71 1427-1433. (https://doi.org/10.1210/jcem-71-6-1427)

Higuchi M, Yoshida S, Ueharu H, Chen M, Kato T \& Kato Y 2014 PRRX1 and PRRX2 distinctively participate in pituitary organogenesis and a cell-supply system. Cell and Tissue Research 357 323-335. (https://doi. org/10.1007/s00441-014-1861-5)

Hofmann BM, Kreutzer J, Saeger W, Buchfelder M, Blümcke I, Fahlbusch R \& Buslei R 2006 Nuclear beta-catenin accumulation as reliable marker for the differentiation between cystic craniopharyngiomas and rathke cleft cysts: a clinico-pathologic approach. American Journal of Surgical Pathology 30 1595-1603. (https://doi.org/10.1097/01.pas.0000213328.64121.12)

Holczbauer Á, Factor VM, Andersen JB, Marquardt JU, Kleiner DE, Raggi C, Kitade M, Seo D, Akita H, Durkin ME, et al. 2013 Modeling pathogenesis of primary liver cancer in lineage-specific mouse cell types. Gastroenterology 145 221-231. (https://doi.org/10.1053/j. gastro.2013.03.013)

Hölsken A, Sill M, Merkle J, Schweizer L, Buchfelder M, Flitsch J, Fahlbusch R, Metzler M, Kool M, Pfister SM, et al. 2016 Adamantinomatous and papillary craniopharyngiomas are characterized by distinct epigenomic as well as mutational and transcriptomic profiles. Acta Neuropathologica Communications 420. (https://doi.org/10.1186/s40478-016-0287-6)

Horiguchi K, Ilmiawati C, Fujiwara K, Tsukada T, Kikuchi M \& Yashiro T 2012 Expression of chemokine CXCL12 and its receptor CXCR4 in folliculostellate (FS) cells of the rat anterior pituitary gland: the CXCL12/CXCR4 axis induces interconnection of FS cells. Endocrinology 153 1717-1724. (https://doi.org/10.1210/en.2011-1937)

Hosoyama T, Nishijo K, Garcia MM, Schaffer BS, OhshimaHosoyama S, Prajapati SI, Davis MD, Grant WF, Scheithauer BW, Marks DL, et al. 2010 A postnatal Pax7 progenitor gives rise to pituitary adenomas. Genes and Cancer $1388-402$. (https://doi. org/10.1177/1947601910370979)

Hsu Y-C, Li L \& Fuchs E 2014 Emerging interactions between skin stem cells and their niches. Nature Medicine 20 847-856. (https://doi.org/10.1038/ $\mathrm{nm} .3643$ )

Di Ieva A, Rotondo F, Syro L V., Cusimano MD \& Kovacs K 2014 Aggressive pituitary adenomas-diagnosis and emerging treatments. Nature Reviews Endocrinology 10 423-435. (https://doi.org/10.1038/ nrendo.2014.64)

Japón MA, Rubinstein M \& Low MJ 1994 In situ hybridization analysis of anterior pituitary hormone gene expression during fetal mouse development. Journal of Histochemistry and Cytochemistry $\mathbf{4 2}$ 1117-1125. (https://doi.org/10.1177/42.8.8027530) 
Japón MA, Urbano AG, Sáez C, Segura DI, Cerro AL, Diéguez C \& Alvarez CV 2002 Glial-derived neurotropic factor and RET gene expression in normal human anterior pituitary cell types and in pituitary tumors. Journal of Clinical Endocrinology and Metabolism 87 1879-1884. (https://doi.org/10.1210/jcem.87.4.8383)

Jaubert A, Drutel G, Leste-Lasserre T, Ichas F \& Bresson-Bepoldin L 2007 Tyrosine hydroxylase and dopamine transporter expression in lactotrophs from postlactating rats: involvement in dopamineinduced apoptosis. Endocrinology 148 2698-2707. (https://doi. org/10.1210/en.2006-1293)

Karavitaki N 2012 Prevalence and incidence of pituitary adenomas. Annales d'Endocrinologie 73 79-80. (https://doi.org/10.1016/j. ando.2012.03.039)

Kelberman D, Rizzoti K, Lovell-Badge R, Robinson ICAF \& Dattani MT 2009 Genetic regulation of pituitary gland development in human and mouse. Endocrine Reviews 30 790-829. (https://doi.org/10.1210/ er.2009-0008)

Kreso A \& Dick JE 2014 Cell stem cell evolution of the cancer stem cell model. Stem Cell 14 275-291. (https://doi.org/10.1016/j. stem.2014.02.006)

Krylyshkina O, Chen J, Mebis L, Denef C \& Vankelecom H 2005 Nestinimmunoreactive cells in rat pituitary are neither hormonal nor typical folliculo-stellate cells. Endocrinology 146 2376-2387. (https://doi. org/10.1210/en.2004-1209)

Kulig E, Jin L, Qian X, Horvath E, Kovacs K, Stefaneanu L, Scheithauer BW \& Lloyd R V 1999 Apoptosis in nontumorous and neoplastic human pituitaries: expression of the Bcl-2 family of proteins. American Journal of Pathology 154 767-774. (https://doi.org/10.1016/ S0002-9440(10)65323-0)

Laberge R-M, Awad P, Campisi J \& Desprez P-Y 2012 Epithelialmesenchymal transition induced by senescent fibroblasts. Cancer Microenvironment 5 39-44. (https://doi.org/10.1007/s12307-011-0069-4)

Lamolet B, Pulichino AM, Lamonerie T, Gauthier Y, Brue T, Enjalbert A \& Drouin J 2001 A pituitary cell-restricted T box factor, Tpit, activates POMC transcription in cooperation with Pitx homeoproteins. Cell 104 849-859. (https://doi.org/10.1016/S0092-8674(01)00282-3)

Langlais D, Couture C, Kmita M \& Drouin J 2013 Adult pituitary cell maintenance: lineage-specific contribution of self-duplication. Molecular Endocrinology 27 1103-1112. (https://doi.org/10.1210/me.2012-1407)

Larkin S \& Ansorge O 2000 Pathology and pathogenesis of pituitary adenomas and other sellar lesions. In EndoText. Eds De Groot LJ, Chrousos G, Dungan K, et al. South Dartmouth, MA, USA: MDText.com. (available at: https://www.ncbi.nlm.nih.gov/books/NBK425704/)

Lepore DA, Roeszler K, Wagner J, Ross SA, Bauer K \& Thomas PQ 2005 Identification and enrichment of colony-forming cells from the adult murine pituitary. Experimental Cell Research 308 166-176. (https://doi. org/10.1016/j.yexcr.2005.04.023)

Levy A 2002 Physiological implications of pituitary trophic activity. Journal of Endocrinology 174 147-155. (https://doi.org/10.1677/ joe.0.1740147)

Lin SC, Li S, Drolet DW \& Rosenfeld MG 1994 Pituitary ontogeny of the Snell dwarf mouse reveals Pit-1-independent and Pit-1-dependent origins of the thyrotrope. Development 120 515-522.

Ma W, Ikeda H \& Yoshimoto T 2002 Clinicopathologic study of 123 cases of prolactin-secreting pituitary adenomas with special reference to multihormone production and clonality of the adenomas. Cancer $\mathbf{9 5}$ 258-266. (https://doi.org/10.1002/cncr.10676)

Manoranjan B, Mahendram S, Almenawer SA, Venugopal C, McFarlane N, Hallett R, Vijayakumar T, Algird A, Murty NK, Sommer DD, et al. 2016 The identification of human pituitary adenoma-initiating cells. Acta Neuropathologica Communications 4 125. (https://doi.org/10.1186/ s40478-016-0394-4)

Mao X, Zhang X, Xue X, Guo G, Wang P, Zhang W, Fei Z, Zhen H, You S \& Yang H 2009 Brain tumor stem-like cells identified by neural stem cell marker CD15. Translational Oncology 2 247-257. (https://doi. org/10.1593/tlo.09136)
Martinez-Barbera JP 2015 Molecular and cellular pathogenesis of adamantinomatous craniopharyngioma. Neuropathology and Applied Neurobiology 41 721-732. (https://doi.org/10.1111/nan.12226)

Martinez-Barbera JP \& Andoniadou CL 2016 Concise review: paracrine role of stem cells in pituitary tumors: a focus on adamantinomatous craniopharyngioma. Stem Cells 34 268-276. (https://doi.org/10.1002/ stem.2267)

Marusyk A \& Polyak K 2010 Tumor heterogeneity: causes and consequences. Biochimica et Biophysica Acta 1805 105-117. (https:// doi.org/10.1016/j.bbcan.2009.11.002)

Megnis K, Mandrika I, Petrovska R, Stukens J, Rovite V, Balcere I, Jansone LS, Peculis R, Pirags V \& Klovins J 2016 Functional characteristics of multipotent mesenchymal stromal cells from pituitary adenomas. Stem Cells International 2016 7103720. (https:// doi.org/10.1155/2016/7103720)

Melmed S 2003 Mechanisms for pituitary tumorigenesis: the plastic pituitary. Journal of Clinical Investigation 112 1603-1618. (https://doi. org/10.1172/JCI20401)

Mertens F, Gremeaux L, Chen J, Fu Q, Willems C, Roose H, Govaere O Roskams T, Cristina C, Becú-Villalobos D, et al. 2015 Pituitary tumors contain a side population with tumor stem cell-associated characteristics. Endocrine-Related Cancer 22 481-504. (https://doi. org/10.1530/ERC-14-0546)

Mescher M, Jeong P, Knapp SK, Rübsam M, Saynisch M, Kranen M, Landsberg J, Schlaak M, Mauch C, Tüting T, et al. 2017 The epidermal polarity protein Par3 is a non-cell autonomous suppressor of malignant melanoma. Journal of Experimental Medicine 214 339-358. (https://doi.org/10.1084/jem.20160596)

Di Mitri D \& Alimonti A 2016 Non-cell-autonomous regulation of cellular senescence in cancer. Trends in Cell Biology 26 215-226. (https://doi. org/10.1016/j.tcb.2015.10.005)

Nguyen LV, Vanner R, Dirks P \& Eaves CJ 2012 Cancer stem cells: an evolving concept. Nature Reviews Cancer 12 133-143. (https://doi.org/10.1038/ nrc3184)

Nicolas M, Wolfer A, Raj K, Kummer JA, Mill P, van Noort M, Hui C, Clevers H, Dotto GP \& Radtke F 2003 Notch1 functions as a tumor suppressor in mouse skin. Nature Genetics 33 416-421. (https://doi.org/10.1038/ ng1099)

Nolan LA, Kavanagh E, Lightman SL \& Levy A 1998 Anterior pituitary cell population control: basal cell turnover and the effects of adrenalectomy and dexamethasone treatment. Journal of Neuroendocrinology 10 207-215. (https://doi.org/10.1046/j.13652826.1998.00191.x)

Nomura R, Yoshida D \& Teramoto A 2009 Stromal cell-derived factor-1 expression in pituitary adenoma tissues and upregulation in hypoxia. Journal of Neuro-Oncology 94 173-181. (https://doi.org/10.1007/s11060009-9835-2)

Oishi Y, Okuda M, Takahashi H, Fujii T \& Morii S 1993 Cellular proliferation in the anterior pituitary gland of normal adult rats: Influences of sex, estrous cycle, and circadian change. Anatomical Record 235 111-120. (https://doi.org/10.1002/ar.1092350111)

Orciani M, Davis S, Appolloni G, Lazzarini R, Mattioli-Belmonte M, Ricciuti RA, Boscaro M, Di Primio R \& Arnaldi G 2014 Isolation and characterization of progenitor mesenchymal cells in human pituitary tumors. Cancer Gene Therapy 22 9-16. (https://doi.org/10.1038/ cgt.2014.63)

Pallini R, Ricci-Vitiani L, Montano N, Mollinari C, Biffoni M, Cenci T, Pierconti F, Martini M, De Maria R \& Larocca LM 2011 Expression of the stem cell marker CD133 in recurrent glioblastoma and its value for prognosis. Cancer 117 162-174. (https://doi.org/10.1002/cncr.25581)

Park CH, Bergsagel DE \& McCulloch EA 1971 Mouse myeloma tumor stem cells: a primary cell culture assay. Journal of the National Cancer Institute 46 411-422. (https://doi.org/10.1093/jnci/46.2.411)

Park J, Euhus DM \& Scherer PE 2011 Paracrine and endocrine effects of adipose tissue on cancer development and progression. Endocrine Reviews 32 550-570. (https://doi.org/10.1210/er.2010-0030) http://joe.endocrinology-journals.org https://doi.org/10.1530/JOE-17-0258
(C) 2018 The authors Published by Bioscientifica Ltd. Printed in Great Britain

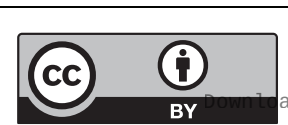

This work is licensed under a Creative Commons Attribution 3.0 Unported License.

ded from Bioscientifica com at $04 / 26 / 2023$ 01:51:13PM 
Patel DM, Shah J \& Srivastava AS 2013 Therapeutic potential of mesenchymal stem cells in regenerative medicine. Stem Cells International 2013 1-15. (https://doi.org/10.1155/2013/496218)

Pérez Millán MI, Brinkmeier ML, Mortensen AH \& Camper SA 2016 PROP1 triggers epithelial-mesenchymal transition-like process in pituitary stem cells. eLife 5 e14470. (https://doi.org/10.7554/ eLife.14470)

Perez-Castro C, Renner U, Haedo MR, Stalla GK \& Arzt E 2012 Cellular and molecular specificity of pituitary gland physiology. Physiological Reviews 92 1-38. (https://doi.org/10.1152/physrev.00003.2011)

Plaks V, Kong N \& Werb Z 2015 The cancer stem cell niche: how essentia is the niche in regulating stemness of tumor cells? Cell Stem Cell $\mathbf{1 6}$ 225-238. (https://doi.org/10.1016/j.stem.2015.02.015)

Read T-A, Fogarty MP, Markant SL, McLendon RE, Wei Z, Ellison DW, Febbo PG \& Wechsler-Reya RJ 2009 Identification of CD15 as a marker for tumor-propagating cells in a mouse model of medulloblastoma. Cancer Cell 15 135-147. (https://doi.org/10.1016/j. ccr.2008.12.016)

Rizzoti K, Akiyama H \& Lovell-Badge R 2013 Mobilized adult pituitary stem cells contribute to endocrine regeneration in response to physiological demand. Cell Stem Cell 13 419-432. (https://doi.org/10.1016/j. stem.2013.07.006)

Sabbath KD, Ball ED, Larcom P, Davis RB \& Griffin JD 1985 Heterogeneity of clonogenic cells in acute myeloblastic leukemia. Journal of Clinical Investigation 75 746-753. (https://doi.org/10.1172/JCI111756)

Schimmer BP \& White PC 2010 Minireview: steroidogenic factor 1: its roles in differentiation, development, and disease. Molecular Endocrinology 24 1322-1337. (https://doi.org/10.1210/me.20090519)

Schulte HM, Oldfield EH, Allolio B, Katz DA, Berkman RA \& Ali IU 1991 Clonal composition of pituitary adenomas in patients with cushing's disease: determination by X-chromosome inactivation analysis. Journal of Clinical Endocrinology and Metabolism 73 1302-1308. (https://doi.org/10.1210/jcem-73-6-1302)

Shackleton M, Quintana E, Fearon ER \& Morrison SJ 2009 Heterogeneity in cancer: cancer stem cells versus clonal evolution. Cell 138 822-829. (https://doi.org/10.1016/j.cell.2009.08.017)

Singh SK, Clarke ID, Terasaki M, Bonn VE, Hawkins C, Squire J \& Dirks PB 2003 Identification of a cancer stem cell in human brain tumors Cancer Research 63 5821-5828.

Southam CM \& Brunschwig A 1961 Quantitative studies of autotransplantation of human cancer Cancer 14 971-978. (https://doi.org/10.1002/1097-0142(196109/10)14:5<971::AIDCNCR2820140510>3.0.CO;2-O)

Stange DE \& Clevers H 2013 Concise review: the Yin and Yang of intestinal (cancer) stem cells and their progenitors. Stem Cells $\mathbf{3 1}$ 2287-2295. (https://doi.org/10.1002/stem.1475)

Suga H, Kadoshima T, Minaguchi M, Ohgushi M, Soen M, Nakano T, Takata N, Wataya T, Muguruma K, Miyoshi H, et al. 2011 Selfformation of functional adenohypophysis in three-dimensional culture. Nature 480 57-62. (https://doi.org/10.1038/nature10637)

Susa T, Kato T, Yoshida S, Yako H, Higuchi M \& Kato Y 2012 Pairedrelated homeodomain proteins Prx1 and Prx2 are expressed in embryonic pituitary stem/progenitor cells and may be involved in the early stage of pituitary differentiation. Journal of Neuroendocrinology 24 1201-1212. (https://doi.org/10.1111/j.13652826.2012.02336.x)

Syro LV, Rotondo F, Ramirez A, Di Ieva A, Sav MA, Restrepo LM, Serna CA \& Kovacs K 2015 Progress in the diagnosis and classification of pituitary adenomas. Frontiers in Endocrinology 6 97. (https://doi. org/10.3389/fendo.2015.00097)

Treier M, O'Connell S, Gleiberman A, Price J, Szeto DP, Burgess R, Chuang PT, McMahon AP \& Rosenfeld MG 2001 Hedgehog signaling is required for pituitary gland development. Development 128 377-386.

Urbano AG, Suárez-Peñaranda M, Diéguez C \& Alvarez CV 2000 GDNF and RET-gene expression in anterior pituitary-cell types. Endocrinology 141 1893-1896. (https://doi.org/10.1210/endo.141.5.7548)

Vaca AM, Guido CB, Sosa L del V, Nicola JP, Mukdsi J, Petiti JP \& Torres AI 2016 The expansion of adult stem/progenitor cells and their marker expression fluctuations are linked with pituitary plastic adaptation during gestation and lactancy. American Journal of Physiology: Endocrinology and Metabolism 311 E367-E379. (https://doi.org/10.1152/ ajpendo.00077.2016)

Vankelecom H 2007 Non-hormonal cell types in the pituitary candidating for stem cell. Seminars in Cell and Developmental Biology 18 559-570. (https://doi.org/10.1016/j.semcdb.2007.04.006)

Vankelecom H 2010 Pituitary stem/progenitor cells: embryonic players in the adult gland? European Journal of Neuroscience 32 2063-2081. (https://doi.org/10.1111/j.1460-9568.2010.07523.x)

Visvader JE \& Lindeman GJ 2008 Cancer stem cells in solid tumours: accumulating evidence and unresolved questions. Nature Reviews Cancer 8 755-768. (https://doi.org/10.1038/nrc2499)

Weiss S, Siebzehnrübl FA, Kreutzer J, Blümcke I \& Buslei R 2009 Evidence for a progenitor cell population in the human pituitary. Clinical Neuropathology 28 309-318. (https://doi.org/10.5414/NPP28309)

Welte Y, Adjaye J, Lehrach HR \& Regenbrecht CR 2010 Cancer stem cells in solid tumors: elusive or illusive? Cell Communication and Signaling 86 . (https://doi.org/10.1186/1478-811X-8-6)

Willems C, Fu Q, Roose H, Mertens F, Cox B, Chen J \& Vankelecom H 2016 Regeneration in the pituitary after cell-ablation injury: timerelated aspects and molecular analysis. Endocrinology 157 705-721. (https://doi.org/10.1210/en.2015-1741)

Wurth R, Barbieri F, Pattarozzi A, Gaudenzi G, Gatto F, Fiaschi P, Ravetti JL, Zona G, Daga A, Persani L, et al. 2016 Phenotypical and pharmacological characterization of stem-like cells in human pituitary adenomas. Molecular Neurobiology 54 4879-4895. (https:// doi.org/10.1007/s12035-016-0025-x)

Xu Q, Yuan X, Tunici P, Liu G, Fan X, Xu M, Hu J, Hwang JY, Farkas DL, Black KL, et al. 2009 Isolation of tumour stem-like cells from benign tumours. British Journal of Cancer 101 303-311. (https://doi. org/10.1038/sj.bjc.6605142)

Yoshida S, Kato T, Susa T, Cai L, Nakayama M \& Kato Y 2009 PROP1 coexists with SOX2 and induces PIT1-commitment cells. Biochemical and Biophysical Research Communications 385 11-15. (https://doi. org/10.1016/j.bbrc.2009.05.027)

Yoshida S, Kato T, Yako H, Susa T, Cai L-Y, Osuna M, Inoue K \& Kato Y 2011 Significant quantitative and qualitative transition in pituitary stem/ progenitor cells occurs during the postnatal development of the rat anterior pituitary. Journal of Neuroendocrinology 23 933-943. (https://doi.org/10.1111/j.1365-2826.2011.02198.x)

Zhu X, Tollkuhn J, Taylor H \& Rosenfeld MG 2015 Notch-dependent pituitary SOX2+ stem cells exhibit a timed functional extinction in regulation of the postnatal gland. Stem Cell Reports 5 1196-1209. (https://doi.org/10.1016/j.stemcr.2015.11.001)

Zomer A, Ellenbroek SIJ, Ritsma L, Beerling E, Vrisekoop N \& Van Rheenen J 2013 Brief report: Intravital imaging of cancer stem cell plasticity in mammary tumors. Stem Cells 31 602-606. (https://doi.org/10.1002/ stem.1296)

Received in final form 22 August 2017

Accepted 30 August 2017

Accepted Preprint published online 30 August 2017 http://joe.endocrinology-journals.org https://doi.org/10.1530/JOE-17-0258
(C) 2018 The authors Published by Bioscientifica Ltd. Printed in Great Britain

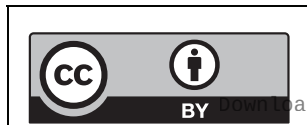

This work is licensed under a Creative Commons Attribution 3.0 Unported License.

ded from Bioscientifica.com at 04/26/2023 01:51:13PM 